\title{
Determination of risk and knowledge levels of individuals with diabetes in terms of health beliefs and cardiovascular diseases
}

\author{
Gürcan Arslan* and Mukadder Mollaoğlu \\ Cumhuriyet University Faculty of Health Sciences Department of Nursing, Turkey
}

\begin{abstract}
Purpose: Purpose of this study has determine the awareness, predisposition, and health belief level of individuals with diabetes towards CVD.

Method: Design of the study was a cross-sectional descriptive. This study adhered to the STROBE guideline for cross-sectional studies.160 diabetic individuals who were diagnosed with diabetes who were treated in the Endocrinology Service between March and July 2019. Data were collected by Demographic and Medical Information, Health Belief Model Score (HBM), The Framingham risk score (FRS) and Cardiovascular Disease Risk factors information level scale (CARRIE-IL).

Result: The HBS total score average $(3.55 \pm 0.28)$ of the individuals involved in the study was found to be negative. The lowest score was determined as perceived obstacles, perceived seriousness, perceived sensitivity, perceived benefits, and health-related activities. The participants' knowledge level of cardiovascular disease risk factors was above average $(16.13 \pm 2.88)$ and their risk of having a cardiovascular disease within ten years was $18.13 \pm 8.96$ (intermediate level). In the study, men with diabetes aged 65 and over, single, elementary school, first-degree obese, less than two per week, physical activity level, and health beliefs of individuals with diabetes for more than 6 years low level of knowledge of CVD and CVD within ten years were determined to be likely to be able to spend any.

Conclusion: Diabetes is a chronic disease, but if it is not well managed, it prepares the ground for the development of cardiovascular diseases. It can prevent cardiovascular complications when nurses identify individuals who need support in the management of diabetes and make plans to improve their specific health protection.
\end{abstract}

\section{Introduction}

Diabetes is the leading cause of mortality in the World. 642 million diabetes cases are expected in the world in 2040 [1]. Diabetes is associated with a 2 - to 4 -fold increase in the risk of cardiovascular disease (CVD) [1,2]. Cardiovascular Disease (CVD) is shown as the most important cause of morbidity and mortality in diabetes [2].

In the international guidelines published, individuals with diabetes are associated to be "at the highest risk level" in terms of CVD risk, and therefore it is recommended to quickly rule out cardiovascular risk factors $[1,3]$. One of the main goals for controlling cardiovascular risk factors in diabetes management is to ensure that the blood glucose level is within normal limits [4]. The most effective way is to determine individual changeable risk factors. Studies have shown that CAD risk factor interventions increase the life expectancy and increase the quality of life [4-6].

In terms of cardiovascular diseases, age, gender, history of cardiovascular disease in first degree relatives are considered as irreversible risk factors; smoking, diabetes, dyslipidemia, hypertension, abdominal obesity and inadequate physical activity are considered as modifiable risk factor [7]. On the other hand, in order to prevent cardiovascular complications in individuals with diabetes, early detection of individual risk factors and raising awareness of these risk factors is very important. For this reason, Health Belief Model (HBM) is used in diabetes patients to determine their health behaviors and beliefs [8].
Previous studies showed successful application of HBM in explanation and prediction of preventive health behavior [6-9]. Based on HBM, individual must believe that he is susceptible to a disease (perceived susceptibility), understands the risk and it's sever to his life (perceived severity), and follow the positive health behaviors such as selfcare behavior [10]. In other studies with individuals with diabetes, it is emphasized that increased level of knowledge on CVD risks and awareness by risk analysis can be effective in preventing complications $[7,8,11]$.

Nurses play an important role in raising awareness in the society, educating individuals and gaining healthy living habits in order to prevent possible complications of diabetes $[12,13]$. In this respect, it is of great importance to increase the belief in health by determining the knowledge and risk levels of individuals with diabetes in terms of CVD.

\section{Purpose}

This study was carried out to determine the awareness, predisposition and health belief levels of individuals with diabetes towards CVD.

*Correspondence to: Gürcan Arslan, Cumhuriyet University Faculty of Health Sciences Department of Nursing, Turkey, ORCID: 000000022235 8084, Twitter: @gurcansolmaz1; E-mail: gurcansolmaz@hotmail.com

Key words: cardiovascular diseases, diabetes, framingham, health belief model, nursing

Received: March 05, 2021; Accepted: March 16, 2021; Published: March 19, 2021 


\section{Method}

\section{Design}

A cross-sectional descriptive study design was used. This study adhered to the Strengthening the Reporting of Observational studies in Epidemiology (STROBE) guideline for cross-sectional studies.

\section{Setting}

The research was carried out at the Endocrinology Service of Sivas Cumhuriyet University Hospital in Turkey.

\section{Participants}

In the study, 160 diabetic individuals who were diagnosed with diabetes who were treated in the Endocrinology Service between March and July 2019, and did not sampling method, were included in the study. The inclusion criteria and exclusion were; those who have severe mental health problems under the age of 18 , at least one year duration of diagnosed diabetes and do not wish to participate in the study were excluded from the study.

\section{Measures}

A self-designed questionnaire derived from the literature was developed to collect data. It consisted of four parts:

\section{Demographic and Medical Information}

The first part of the questionnaire was 24 questions that was related to demographic variables such as age, education, occupation, marital status, disease history, type of treatment and metabolic parameters of patients; total cholesterol, triglyceride, low density lipoprotein (LDL) cholesterol, high density lipoprotein (HDL) cholesterol, systolic blood pressure (SBP), diastolic blood pressure (DBP) and glycosylated hemoglobin (HbA1c). Participants' height, weight and blood pressure were measured as part of the physical examination. Weight and height of the patients were measured and body mass index (BMI) was calculated.

\section{Health Belief Model Score (HBM)}

The items which assessed components of the HBM with use two standard questionnaires and 33 items were composed under four major constructs, (1) perceived susceptibility; (2) perceived severity; (3) perceived benefit; (4) perceived barrier; (5) perceived self-efficacy. Four items were designed to measure perceived susceptibility (e.g. "I do not get diabetes complications"). Ten items were designed to measure perceived severity (e.g. "I think that diabetes is a serious disease"). Six items were designed to perceive benefit of self-efficacy to selfmanagement (e.g. "Proper diabetic diet is effective for control blood sugar"). Ten items were designed to evaluate perceived barrier to selfmanagement (e.g. "Diet for diabetics is annoying me"). Six items were designed to perceived self-efficacy to self-management (e.g. "How you sure the ability to diabetic diet?"). In order to facilitate respondents' responses to the items, all items were standardized to a 5-point. Likert scale, ranging from 1 (strongly disagree) to 5 (strongly agree). For selfefficacy scale, ranging from 1 (very little) to 5 (very much). A score of 4 on the scale items presents a high (positive) health belief, and a score $<4$ on a low (negative) health belief .Estimated reliability coefficients for each HBM constructs questionnaires were as follows: Severity ( $\alpha$ $=0.69)$; susceptibility $(\alpha=0.71)$; barrier $(\alpha=0.62)$; benefit $(\alpha=0.75)$; self-efficacy $(\alpha=0.76)$, and knowledge $(\alpha=0.66)$ [8].

\section{The Framingham risk score (FRS)}

FRS has evolved as validated means of predicting cardiovascular disease (CVD) risk in asymptomatic patients. In this system, gender, age, smoking, family history of cardiovascular disease diabetes containing the contents, the available fasting blood glucose $(>100$ $\mathrm{mg}$ ), height, weight, waist circumference,SBP, and DBP, being under antihypertensive treatment, total cholesterol, HDL-cholesterol, LDLcholesterol, triglycerides so coronary death within 10 years is calculated into the risk of myocardial infarction. Risk is considered low if the FRS is less than $10 \%$, moderate if it is $10 \%$ to $19 \%$, and high if it is $20 \%$ or higher.

\section{Cardiovascular disease Risk factors information level scale (CARRIF-IL)}

Arikan, et al. (Arikan, 2009) a study of validity and reliability was developed by in 2009. the scale consists of Twenty-eight items. the first four items on the scale are related to cardiovascular disease characteristics, prevention and age factor, while 15 items question the risk factors and nine items question the outcome of change in risk behaviors. Participants are asked to answer "Yes", "No" or "I do not know". 1 point is given to each correct answer on the scale. six questions $(11,12,16,17,24,26)$ it is scored in the opposite direction. Scores between 0-28 can be taken from the scale. As scores rise, the level of knowledge increases. Arikan, et al. [14] found the cronbach alpha value of the scale to be 0.76 .

\section{Data collection}

Each participant was asked to complete the questionnaire in the hospitals. Four research instruments were used to collect the data. Data was collected by the researcher with face to face interview technique and measuring the height, weight, blood pressure of the individuals. Filling out data forms and making measurements approximately 25-30 min. lasted.

\section{Data analysis}

The research data were loaded on the Statistical Package for the Social Sciences (SPSS) for Windows Program, version 23.0. The percentage calculation, mean, test of significance between two means analysis of variance, Mann-Whitney U test and Kruskal Wallis test were used in the analysis of the data. The data were evaluated in tables, taking arithmetic means and standard deviation at 0.05 .

\section{Result}

In Table 1, more than half (58.8\%) of the individuals involved in the study were female and $78.8 \%$ were under the age of 65 . Nearly all of the participants (90.6\%) were primary school graduates and $58.1 \%$ were overweight. It was determined that $82.5 \%$ of individuals exercised 1 or 2 times a week, $52.5 \%$ had a period of 1 to 5 years of illness, and $64.4 \%$ used one antidiabetic drug per day. (Table 1).

In Table 2, the HBS total and lower dimensions, CARRIF-IL and Framingham risk Score averages of individuals with diabetes were evaluated. The HBS total score average $(3.55 \pm 0.28)$ of the individuals involved in the study was found to be negative. The lowest score was determined as perceived obstacles, perceived seriousness, perceived sensitivity, perceived benefits and health-related activities. The participants ' knowledge level of cardiovascular disease risk factors was above average $(16.13 \pm 2.88)$ and their risk of having a cardiovascular disease within ten years was $18.13 \pm 8.96$ (intermediate level). 
Table 1. Descriptive statistics of respondents

\begin{tabular}{|c|c|}
\hline Sociodemographic Characteristics & n (\%) \\
\hline \multicolumn{2}{|l|}{ Gender } \\
\hline Female & $94(58.8)$ \\
\hline Male & $66(41.3)$ \\
\hline \multicolumn{2}{|l|}{ Age Group (year) } \\
\hline$<65$ age & $126(78.8)$ \\
\hline$\geq 65$ age & $34(21.2)$ \\
\hline Age Mean (year) $(X \pm S D)($ Min-Max) & $58.86(22-82)$ \\
\hline \multicolumn{2}{|l|}{ Educational Status } \\
\hline Read and write know & $5(3.2)$ \\
\hline Primary education & $145(90.6)$ \\
\hline High school and above & $10(6.2)$ \\
\hline \multicolumn{2}{|l|}{ Marital Status } \\
\hline Married & $126(78.7)$ \\
\hline Single & $34(21.2)$ \\
\hline \multicolumn{2}{|l|}{ BMI ( kg/m²) } \\
\hline Normal weight(18.5-24.9) & $57(35.6)$ \\
\hline Over weight (25-29.9) & $93(58.1)$ \\
\hline First degree obese $(\geq 30)$ & $10(6.3)$ \\
\hline \multicolumn{2}{|l|}{ Regular Exercise } \\
\hline 1-2 days weekly & $132(82.5)$ \\
\hline$\geq 3$ weekly & $15(9.4)$ \\
\hline No & $13(8.1)$ \\
\hline \multicolumn{2}{|l|}{ Disease Diagnosis Age } \\
\hline$\leq 30$ & $48(30.0)$ \\
\hline$\geq 31$ & $112(70.0)$ \\
\hline \multicolumn{2}{|l|}{ Duration of Ilness (years) } \\
\hline $1-5$ year & $84(52.5)$ \\
\hline 6-10 year & $37(23.1)$ \\
\hline$\geq 11$ year & $39(24.4)$ \\
\hline Duration of Ilness (years) $(X \pm S D)$ (Min-Max) & $11.79(1-35)$ \\
\hline \multicolumn{2}{|l|}{ Number of Antidiabetic Drugs (day / number) } \\
\hline Single & $103(64.4)$ \\
\hline Combined (two and above) & $57(35.6)$ \\
\hline $\begin{array}{l}\text { Number of Antidiabetic Drugs (day / number) }(\mathrm{X} \pm \mathrm{SD}) \\
\text { (Min-Max) }\end{array}$ & $1.35(1-2)$ \\
\hline Sociodemographic Characteristics & n (\%) \\
\hline \multicolumn{2}{|l|}{ Gender } \\
\hline Female & $94(58.8)$ \\
\hline Male & $66(41.3)$ \\
\hline \multicolumn{2}{|l|}{ Age Group (year) } \\
\hline$<65$ age & $126(78.8)$ \\
\hline$\geq 65$ age & $34(21.2)$ \\
\hline Age Mean (year) $(X \pm S D)($ Min-Max) & $58.86(22-82)$ \\
\hline \multicolumn{2}{|l|}{ Educational Status } \\
\hline Read and write know & $5(3.2)$ \\
\hline Primary education & $145(90.6)$ \\
\hline High school and above & $10(6.2)$ \\
\hline \multicolumn{2}{|l|}{ Marital Status } \\
\hline Married & $126(78.7)$ \\
\hline Single & $34(21.2)$ \\
\hline \multicolumn{2}{|l|}{ BMI ( kg/m²) } \\
\hline Normal weight(18.5-24.9) & $57(35.6)$ \\
\hline Over weight (25-29.9) & $93(58.1)$ \\
\hline First degree obese $(\geq 30)$ & $10(6.3)$ \\
\hline \multicolumn{2}{|l|}{ Regular Exercise } \\
\hline 1-2 days weekly & $132(82.5)$ \\
\hline$\geq 3$ weekly & $15(9.4)$ \\
\hline No & $13(8.1)$ \\
\hline \multicolumn{2}{|l|}{ Disease Diagnosis Age } \\
\hline$\leq 30$ & $48(30.0)$ \\
\hline
\end{tabular}

\begin{tabular}{|c|c|}
\hline$\geq 31$ & $112(70.0)$ \\
\hline \multicolumn{2}{|l|}{ Duration of Ilness (years) } \\
\hline $1-5$ year & $84(52.5)$ \\
\hline 6-10 year & $37(23.1)$ \\
\hline$\geq 11$ year & $39(24.4)$ \\
\hline Duration of Ilness (years) $(X \pm S D)($ Min-Max) & $11.79(1-35)$ \\
\hline \multicolumn{2}{|l|}{ Number of Antidiabetic Drugs (day / number) } \\
\hline Single & $103(64.4)$ \\
\hline Combined (two and above) & $57(35.6)$ \\
\hline $\begin{array}{l}\text { Number of Antidiabetic Drugs (day / number })(X \pm S D) \\
\text { (Min-Max) }\end{array}$ & $1.35(1-2)$ \\
\hline
\end{tabular}

Table 2. Mean Average Distribution of Participants' Scales and FRS $(n=160)$

\begin{tabular}{|c|c|c|}
\hline Scales & Min-Max & $\mathbf{X} \pm$ SD \\
\hline HBS & $3.00-4.71$ & $3.55 \pm 0.28$ \\
\hline Susceptibility & $2.50-4.25$ & $3.56 \pm 0.39$ \\
\hline Severity & $2.00-4.00$ & $3.51 \pm 0.74$ \\
\hline Benefits & $1.83-5.00$ & $3.58 \pm 0.66$ \\
\hline Barriers & $2.00-4.78$ & $3.21 \pm 0.53$ \\
\hline Health behaviors & $3.10-5.00$ & $3.88 \pm 0.25$ \\
\hline CARRIF-IL & $7-22$ & $16.13 \pm 2.88$ \\
\hline FRS & $1-45$ & $18.13 \pm 8.96$ \\
\hline
\end{tabular}

Table 3, the demographic characteristics of individuals with diabetes was evaluated HBS $(\mathrm{p}<0.001)$, CARRIF-IL $(\mathrm{p}=0.002)$, Framingham $(p=0.035)$ with sex; HBS $(p=0.017)$, Framingham $(\mathrm{p}<0.001)$ with age; Framingham $(\mathrm{p}=0.006)$ with educational status; HBS $(\mathrm{p}=0.003)$, Framingham $(\mathrm{p}<0.001)$ with physical activity; HBS $(\mathrm{p}=0.042)$, CARRIF-IL $(\mathrm{p}=0.001)$ and Framingham $(\mathrm{p}=0.003)$ with the duration of the disease there was statistically significant difference in calculations.

\section{Discussion}

In the study, Framingham risk assessment was moderate and the mean scores of HBS and HBS sub-dimensions were determined as bad / negative. The worst / negative score among the SIM sub-dimensions was taken from the "obstacles" and "seriousness" and the best / positive score from the "recommended activities related to health" area (Table 2). These results can be interpreted as individuals' knowledge levels about cardiovascular diseases have a positive attitude towards health-related activities, while they are not serious enough to overcome barriers. In the literature, studies supporting health research and cardiovascular risk in individuals with diabetes have supported this research [18-20].

Gender, which is one of the main factors determining social health, is accepted as an effective variable on health-related behaviors [21]. In our study, while the mean score of HBS, CARRIF-IL was good / positive compared to men, Framingham risk average was low and statistically significant $(\mathrm{p}<0.001)$ (Table 3$)$. In parallel with our study, Akar et al. [22] it has been determined that women have more positive behaviors compared to men in carrying out their health behaviors with positive diabetic beliefs in diabetes, however, in some studies with patients with diabetes, there was no significant relationship between gender and health belief [22-24].

While all these factors show that the perceptions of women towards protecting and improving their health are positive, this situation is thought to be reflected in our findings .

In the studies conducted, it is emphasized that women with diabetes have 2-3 times more risks about CVD risk than men and that they should be informed about this issue and support their health [25- 
Table 3. Sociodemographic characteristics of individuals with diabetes and its relationship with diabetes HBS, CARRIF-IL and FRS averaging variables ( $\mathrm{n}=160$ )

\begin{tabular}{|c|c|c|c|}
\hline Sociodemographic characteristics & $\begin{array}{c}\text { HBS } \\
\mathbf{X} \pm \text { SD }\end{array}$ & $\begin{array}{c}\text { CARRIF-IL } \\
\mathbf{X} \pm \mathrm{SD}\end{array}$ & $\begin{array}{c}\text { FRS } \\
X \pm \text { SD }\end{array}$ \\
\hline \multicolumn{4}{|l|}{ Gender } \\
\hline Female & $3.75 \pm 0.36$ & $16.95 \pm 5.74$ & $16.88 \pm 7.62$ \\
\hline Male & $3.51 \pm 0.40$ & $15.36 \pm 2.92$ & $19.90 \pm 10.38$ \\
\hline $\mathrm{p}^{*}$ & $\mathbf{p}<0.001$ & $p=0.002$ & $p=0.035$ \\
\hline \multicolumn{4}{|l|}{ Age } \\
\hline$<65$ year & $3.81 \pm 0.45$ & $16.43 \pm 4.36$ & $11.08 \pm 7.75$ \\
\hline$\geq 65$ year & $3.61 \pm 0.37$ & $14.47 \pm 4.09$ & $20.03 \pm 8.32$ \\
\hline $\mathrm{p}^{*}$ & $p=0.017$ & $\mathrm{p}=0.073$ & $\mathrm{p}<0.001$ \\
\hline \multicolumn{4}{|l|}{ Marital Status } \\
\hline Married & $3.69 \pm 0.39$ & $16.04 \pm 4.51$ & $17.14 \pm 9.34$ \\
\hline Single & $3.64 \pm 0.40$ & $15.91 \pm 3.84$ & $18.39 \pm 8.87$ \\
\hline $\mathrm{p}^{*}$ & $\mathrm{p}=0.0588$ & $\mathrm{p}=0.895$ & $\mathrm{p}=0.286$ \\
\hline \multicolumn{4}{|l|}{ Educational Status } \\
\hline Read and write know & $3.97 \pm 0.54$ & $18.40 \pm 6.80$ & $38.40 \pm 10.85$ \\
\hline Primary education & $3.63 \pm 0.38$ & $15.80 \pm 2.76$ & $17.06 \pm 6.72$ \\
\hline High school and above & $3.82 \pm 0.49$ & $18.04 \pm 13.65$ & $23.40 \pm 19.15$ \\
\hline p** & $\mathrm{p}=0.066$ & $\mathrm{p}=0.733$ & $\mathrm{p}=0.006$ \\
\hline \multicolumn{4}{|l|}{ Regular Exercise } \\
\hline 1-2 days weekly & $3.77 \pm 0.45$ & $16.80 \pm 3.48$ & $23.73 \pm 2.28$ \\
\hline$\geq 3$ weekly & $3.92 \pm 0.31$ & $19.53 \pm 10.33$ & $16.18 \pm 6.80$ \\
\hline No & $3.61 \pm 0.38$ & $15.58 \pm 3.26$ & $31.38 \pm 16.79$ \\
\hline $\mathrm{p}^{* *}$ & $p=0.003$ & $\mathrm{p}=0.166$ & $\mathrm{p}<0.001$ \\
\hline \multicolumn{4}{|l|}{ Duration of Ilness (years) } \\
\hline $1-5$ year & $3.68 \pm 0.45$ & $14.48 \pm 3.14$ & $14.59 \pm 3.67$ \\
\hline 6-10 year & $3.62 \pm 0.25$ & $17.32 \pm 2.79$ & $17.82 \pm 8.03$ \\
\hline$\geq 11$ year & $3.65 \pm 0.38$ & $18.07 \pm 6.30$ & $22.15 \pm 12.39$ \\
\hline $\mathrm{p}^{* *}$ & $p=0.042$ & $\mathrm{p}=0.001$ & $\mathrm{p}=\mathbf{0 . 0 0 3}$ \\
\hline
\end{tabular}

Mann Whitney U Test*

Kruskal Wallis Test**

27]. With this study, it can be suggested that individuals with diabetes should reflect gender differences in their care plans while planning the steps to protect and improve health against CVD awareness and development risk.

The difference between the mean score of HBS, CARRIF-IL and FRS from the participants aged 65 and over was found statistically significant $(\mathrm{p}<0.05)$ (Table 3). It can be concluded that individuals under the age of 65 have positive attitudes and behaviors towards diabetes and Framingham risk averages are low accordingly. In addition, it can be said that individuals with age 65 and older have been prolonged with the disease over the years, and individuals have failed to manage their illnesses with diabetes [22]. Therefore, it can be interpreted that elderly patients with diabetes should be handled separately.

According to the single participants of the married participants in the study, the mean score of HBS and CARRIF-IL was high, and the Framingham risk mean was low and statistically insignificant ( $\mathrm{p}>$ 0.05) (Table 3). In our study, the reason for the poor scores of single individuals compared to married individuals can be explained by the low number of single individuals. In a study conducted, no statistical difference was found between marital status and health belief in parallel with our results [28]. In studies conducted, it is stated that individuals with diabetes who are married manage their disease process better than those who are single $[23,28,29]$.

No statistically significant difference was determined when the participants' educational status and HBS, CARRIF-IL and FRS subdimensions were compared. According to the other education levels of those with high school or higher education levels in the study, the mean score of HBS and CARRIF-IL was good / positive FRS and a statistically significant difference was not determined $(\mathrm{p}>0.05)$ (Table 3). Contrary to our study, studies have reported that there is a statistically significant difference between scales and education level $[22,28]$. In line with these results, it is thought that patients with low education level should be especially handled as a risk group in managing diabetes. Nurses should give priority to individuals with low level of education in their diabetes education, and it may be beneficial for them to carry out education programs in accordance with their needs and learning characteristics [30].

In the study, individuals with overweight in BMI classification were found to be higher and statistically significant $(\mathrm{p}<0.05)$ compared to others, whereas FRS of individuals with 1st degree obese was higher ( $p>0.05$ ) (Table 3). In our study, it is expected that individuals who are overweight have good health belief level / positive and disease information for cardiovascular risks and therefore lower FRS than other groups. It gives information about the adaptation of individuals with BMI diabetes to lifestyle changes [29,31]. Adequate-balanced diet in diabetes control, decreasing salt consumption and increasing physical activity ensures that $\mathrm{BMI}$ is within normal limits while decreasing the risk of CVD [32]. It can be interpreted as an expected condition that diabetic individuals have good compliance with the treatment and metabolic values such as BMI are within normal limits.

In the study, those who had a physical activity level of three or more per week were found to be HBS $(\mathrm{p}<0.05)$ and FRS ( $\mathrm{p}<0.001)$ compared to other groups, and to be CARRIF-IL ( $p>0.05$ ) (Table 3). Similar findings were found in our studies with our study $[8,17]$. Physical activity is one of the most important cornerstones of diabetes treatment [17]. Since physical activity prevents weight loss and obesity, 
it can prevent the development of cardiovascular disease in individuals with diabetes [33]. In a randomized trial of AHEAD, symptoms of CVD appear insidiously in individuals with diabetes. Therefore, physical activity programs can be planned for individuals with diabetes starting from low-level exercises since the first diagnosis phase. ${ }^{31}$ In this regard, they can help nurses with individual multidisciplinary team work to organize individual exercise programs [22].

The mean score of HBS and CARRIF-IL was higher, FRS was low and statistically significant compared to the others with a disease duration of $1-5$ years $(\mathrm{p}<0.05)$ (Table 3$)$. In line with these results, the findings of our study are similar to the literatüre [25,27]. Increasing time spent with the disease may affect the health of the individual such as diabetes, coping and adaptation to the diabetes in the future, or may have negative effects on their metabolic values [25]. In addition to all these, the development of micro complications and macro complications that may occur over the years due to the disease may contribute to the formation of negative beliefs against the disease $[8,22]$.

\section{Limitations}

The limitions of the study are that the study is done for a certain period of time and the study is done only in the university hospital.

\section{Conclusion}

Diabetes is a chronic disease, but if it is not well managed, it prepares the ground for the development of cardiovascular diseases. It can prevent cardiovascular complications when nurses identify individuals who need support in the management of diabetes and make plans to improve their specific health protection. We did in the study, men with diabetes aged 65 and over, single, elementary school, first-degree obese, less than two per week, physical activity level, and health beliefs of individuals with diabetes for more than 6 years low level of knowledge of CVD and CVD within ten years were determined to be likely to be able to spend any. Therefore, especially in individuals with cardiovascular complications which may develop in this group should be informed about diabetes and health belief about diabetes that need diabetes education and to increase levels of health centers using nurses home care services can take an active role in the design of programs and responsibilities.

\section{Funding}

No funding support has been received for the study.

\section{References}

1. American Diabetes Association (2019) 2. Classification and diagnosis of diabetes: standards of medical care in diabetes-2019. Diabetes care 42: S13-S28.

2. Haffner SM, Lehto S, Rönnemaa T, Pyörälä K, Laakso M (1998) Mortality from coronary heart disease in subjects with type 2 diabetes and in nondiabetic subjects with and without prior myocardial infarction. $N$ Engl J Med 339: 229-234. [Crossref]

3. Sonmez A, Haymana C, Bayram F, Salman S, Dizdar OS, Gurkan, et al. (2018) Turkish nationwide survEy of glycemic and other Metabolic parameters of patients with Diabetes mellitus (TEMD study). Diabetes Res Clin Pract 146: 138-147. [Crossref]

4. Keskin Ö, Balci B (2011) Diabetes Mellitus and Cardiovasculary Complications. Kafkas Journal of Medical Sciences 2: 81-85.

5. Voogdt-Pruis H, Vrijhoef HJM, Beusmans GHMI (2011) Benefits of nurse-led cardiovascular prevention for patients with type 1 diabetes. Evidence-based nursing 14: 104-105.

6. Spahn JM, Reeves RS, Keim KS, Laquatra I, Kellogg M, et al. (2010) State of the evidence regarding behavior change theories and strategies in nutrition counseling to facilitate health and food behavior change. J Am Diet Assoc 110: 879-891. [Crossref]

7. Bartels DW, Davidson MH, Gong WC (2007) Type 2 diabetes and cardiovascular disease: reducing the risk. Journal of Managed Care Pharmacy 13: 1-17.
8. Kartal A, Özsoy SA (2014) Tip 2 diyabetli hastalarda planli eğitim programinin sağlik inancina ve metabolik kontrole etkisi. Hacettepe Üniversitesi Hemşirelik Fakültesi Dergisi 1: 1-15.

9. Morowatisharifabad M, Rouhani Tonekaboni N (2008) Perceived self-efficacy in selfcare behaviors among diabetic patients referring to Yazd Diabetes Research Center. Journal of Birjand University of Medical Sciences 15: 91-99.

10. Didarloo A, Shojaeizadeh D, Eftekhar Ardebili H, Niknami S, Hajizadeh E, et al. (2011) Assessment of factors affecting self-care behavior among women with type 2 diabetes in Khoy City Diabetes Clinic using the extended theory of reasoned action. Journal of School of Public Health \& Institute of Public Health Research 9: 2.

11. Qiu S, Cai X, Schumann U, Velders M, Sun Z, et al. (2014) Impact of walking on glycemic control and other cardiovascular risk factors in type 2 diabetes: a metaanalysis. PloS one 9: e109767.

12. Turkmen K, Ozbek O, Kayikcioğlu H, Kayrak M, Solak Y, et al. (2012) The relationship between epicardial adipose tissue and coronary artery calcification in peritoneal dialysis patients. Cardiorenal Med 2: 43-51. [Crossref]

13. Yilmaz T, Yilmaz A (2016) Relationship between altered platelet morphological parameters and retinopathy in patients with type 2 diabetes mellitus. J Ophthalmology 2016: 9213623. [Crossref]

14. Arikan I, Metintas S, Kalyoncu C, Yildiz Z (2009) Kardiyovasküler hastaliklar risk faktörleri bilgi düzeyi (KARRİF-BD) ölçeği'nin geçerlik ve güvenirliği. Türk Kardiyol Dern Arş-Arch Turk Soc Cardiol 37: 35-40.

15. Cohen MA (1988) Some new evidence on the seriousness of crime. Criminology 26 343-353.

16. Kara K, Cinar S (2011) The relation between diabetes care profile and metabolic control variables. Kafkas J Med Sci 1: 57-63. [Crossref]

17. Nissen SE, Wolski K (2007) Effect of rosiglitazone on the risk of myocardial infarction and death from cardiovascular causes. New England Journal of Medicine 356: 2457-2471.

18. Britner SL (2002) Science self-efficacy of African American middle school students: Relationship to motivation self-beliefs, achievement, gender, and gender orientation. Emory University, United States, Georgia.

19. Meriç M, Oflaz F (2010) Anksiyolitik ve Antidepresan Kullanan Hastalarin Sağlik İnanç Modeline Dayali Tedaviyle İlgili Düşüncelerinin Tedaviyi Birakma ile İlişkisi. TAF Preventive Medicine Bulletin, 9: 5.

20. Sağ R (2010) Etkinlik teorisine göre zenginleştirilmiş birleştirilmiş siniflarda öğretim uygulamalarinin adaylarin özyeterlik algilarina etkisi. Eğitim ve Bilim 35: 158.

21. Şavran TG (2014) Sağlikta toplumsal cinsiyet eşitsizlikleri: Eskişehir'de kirsal ve kentsel alanlarda kadin sağliği. Fe Dergi 6: 96-115.

22. Zehra AKAR, Bebiș H, Özdemir S (2014) Diyabetli Hastalarin Bazi Sosyo-Demografik Özellikleri İle Sağlik İnançlari Arasindaki İlişki. Ege Üniversitesi Hemşirelik Fakültesi Dergisi 30: 32-46.

23. Hayden J (2017) Introduction to health behavior theory. Jones \& Bartlett Learning.

24. Tan MY (2004) The relationship of health beliefs and complication prevention behaviors of Chinese individuals with Type 2 Diabetes Mellitus. Diabetes Res Clin Pract 66: 71-77. [Crossref]

25. Mosca L, Hammond G, Mochari-Greenberger H, Towfighi A, Albert MA (2013) Fifteen-year trends in awareness of heart disease in women: results of a 2012 American Heart Association national survey. Circulation 127: 1254-1263. [Crossref]

26. Huxley RR, Peters SA, Mishra GD, Woodward M (2015) Risk of all-cause mortality and vascular events in women versus men with type 1 diabetes: a systematic review and meta-analysis. Lancet Diabetes Endocrinol 3: 198-206. [Crossref]

27. Norhammar A, Schenck-Gustafsson K (2013) Type 2 diabetes and cardiovascular disease in women. Diabetologia 56: 1-9. [Crossref]

28. Gökdoğan F, Akinci F (2001) Bolu'da yașayan diyabetlilerin sağlik ve hastaliklarini algilamalari ile uygulamalari. C.Ü. Hemşirelik Yüksekokulu Dergisi 5: 1.

29. Mohebi S, Azadbakht L, Feizi A, Sharifirad G, Kargar M (2013) Review the key role of self-efficacy in diabetes care. Journal of education and health promotion 2: 36.

30. Yağci S, Karabulutlu EY (2017) Tip 2 Diyabetli Hastalarin Sağlik İnanci, Hastalik Tutumlari ve Metabolik Kontrolünün Değerlendirilmesi. Kirikkale Üniversitesi Tip Fakültesi Dergisi 19: 149-157.

31. Schellenberg ES, Dryden DM, Vandermeer B, Ha C, Korownyk C (2013) Lifestyle interventions for patients with and at risk for type 2 diabetes: a systematic review and meta-analysis. Ann Intern Med 159: 543-551. [Crossref] 
Arslan G (2021) Determination of risk and knowledge levels of individuals with diabetes in terms of health beliefs and cardiovascular diseases

32. Heymsfield SB, Wadden TA. (2017) Mechanisms, pathophysiology, and management of obesity. N Engl J Med 376: 254-266. [Crossref]
33. Wanner C, Inzucchi SE, Lachin JM, Fitchett D, von Eynatten M, et al. (2016) Empagliflozin and progression of kidney disease in type 2 diabetes. $N$ Engl J Med 375 323-334. [Crossref]

Copyright: (C2021 Arslan G. This is an open-access article distributed under the terms of the Creative Commons Attribution License, which permits unrestricted use, distribution, and reproduction in any medium, provided the original author and source are credited. 